\title{
Turist Rehberlerinin Mesleki Yeterliliklerinin Destinasyon İmajına ve Memnuniyetine Etkisi*
}

The Effect of Tourist Guides' Professional Competences on Destination Image and Satisfaction

\author{
Caner ÜNAL**, Meltem CABER*** \\ **Arş. Gör., Antalya Bilim Üniversitesi, Turizm Fakültesi, Turizm ve Otel işletmeciliği Bölümü, Çıplaklı Mah. Akdeniz Bulvarı No: 290 A, 07190, Döşemealtı, \\ Antalya. \\ E-posta: caner.unal@antalya.edu.tr \\ ORCID No: 0000-0002-2591-3389 \\ ***Doç. Dr., Akdeniz Üniversitesi Turizm Fakültesi, Turizm Rehberliği Bölümü, Dumlupınar Bulvarı, 07058, Kampüs, Antalya. \\ E-posta: meltemcaber@akdeniz.edu.tr \\ ORCID: 0000-0001-5191-373X
}

MAKALE BILGILERI

Makale işlem bilgileri:

Gönderilme tarihi: 29 Ağustos 2018

Düzeltme: 10 Kasım 2018

Kabul: 4 Aralık 2018

Anahtar sözcükler: Turist rehberliği, Mesleki yeterlilik, Destinasyon imaji, Turist memnuniyeti, Antalya.

\section{ARTICLE INFO}

Article history:

Submitted: : 29 August 2018

Resubmitted: 10 November 2018

Accepted: 4 December 2018

Key words: Tourist guiding,

Professional competence, Destination

image, Tourist satisfaction, Antalya.

\section{öz}

Turizm ile ilgili alanyazında turistlerin ziyaret ettikleri destinasyonlara yönelik imaj algıları ve genel memnuniyetleri ile kendilerine eșlik eden turist rehberlerine yönelik değerlendirmeleri bir arada ele alan sınırlı sayıda çalışma mevcuttur. Bu çalışmanın başııca amacı, turistlerin katıldıkları turu yöneten turist rehberinin mesleki yeterliliğine yönelik algılarının, destinasyona yönelik imajlarına ve memnuniyetlerine etkisini ortaya koyabilmektir. Araştırmadan elde edilen bulguların, bu değişkenler arasındaki ilişkiyi açıklamaya katkı sağlayacağı öngörülmüștür. Bu amaçla ilgili alanyazındaki kuramsal ve deneysel çalıșmalardan yararlanılarak, bir araştırma modeli geliştirilmiştir. Modelin test edilebilmesi amacıyla, kolayda örneklem yöntemi ile Antalya şehir turuna katılan Alman turistlere yönelik bir anket çalışması gerçekleştirilerek, 307 adet veri toplanmıştır. Araștırma sonuçları, turist rehberlerinin mesleki yeterlilikleri, algılanan destinasyon imajı ve genel memnuniyet arasında istatistiki açıdan anlamlı bir ilişki olduğunu göstermiştir. Turist rehberinin mesleki yeterliliğinin turist memnuniyeti üzerindeki etkisi yüksek bir seviyededir. Destinasyon imajının bilişsel boyutunda 'sosyal çevre ve olanaklar' ve duygusal boyutunda 'canlandırıcı'lık, genel turist memnuniyetine en fazla etki yapan hususlardır.

\begin{abstract}
Limited number of studies exists in the tourism literature that examine together the tourists' destination image perceptions, their overall satisfactions, and evaluations about tourist guides. The principle aim of this study is to be able to unveil the impact of tourists' perception of the professional competence of tourists guides on the tourists' perceived destination image and tourists' overall satisfaction with destinations. The findings, which obtained from the research, it is foreseen that will have contribution to understanding the relationship between these variables. For this purpose, a research model was developed on the basis of existing theoretical and empirical studies in the tourism literature. In order to test the model, a survey was conducted using convenience sampling method. and data were collected from 307 German tourists who participated in an Antalya city tour. Research findings indicated that there were significant relationships among the professional competence of tourists guides, perceived destination image and overall satisfaction. The impact of tourist guide competence on overall tourist satisfaction is identified high. 'Social environment and facilities' under cognitive dimension and 'restorative' under affective dimension of subjects that have the highest impact on over satisfaction.
\end{abstract}

\footnotetext{
* Bu çalışma, Caner Ünal'ın Akdeniz Üniversitesi, Sosyal Bilimler Enstitüsü, Turizm İşletmeciliği ve Otelcilik Anabilim Dalı yüksek lisans programında Doç. Dr. Meltem Caber danışmanlığında yürütülmüş ve 2015 yılında tamamlanarak kabul edilmiş olan "Profesyonel Turist Rehberlerinin Mesleki Yeterliliklerinin Turistlerin Destinasyon Imaj Algisı ve Genel Memnuniyeti Üzerine Etkisi (Alman Turistlere Yönelik Antalya Şehir Turunda Bir (Uygulama)" başlıklı yüksek lisans tezinden türetilmiştir.
}

\section{GíRiş}

Uluslararası turizm hareketlerinin artmasıyla birlikte yüksek turist memnuniyeti sağlamak hem turizm işletmeleri hem de destinasyonlar açısından önemli bir hedef haline gelmiştir. Bu bağlamda turistlerin ziyaret ettikleri destinasyonlarda kendilerine günübirlik veya daha uzun 
süreli yerel turlarda eşlik eden turist rehberlerinin hizmet sunumları ve mesleki yeterliliklerinin ve bu hususlarin genel turist memnuniyeti üzerindeki etkisinin incelenmesi gerekmektedir. Turist rehberlerinin performansları ile turistlerin memnuniyetleri arasındaki ilişkiyi ele alan bazı araştırmacilar (Geva ve Goldman 1991; Weiler ve Ham 2002; Zhang ve Chow 2004; Huang, Hsu ve Chan 2010) ilgili alanyazına katkı sağlamışlardır. Geçmiş çalışmaların sonuçları ışı̆̆ında, araştırmacilar turist memnuniyetinin tur hizmetleri, rehber hizmetleri ve genel tur deneyiminden oluşan üç alt boyutta ele alınmasını önermiştir (Huang, Hsu ve Chan 2010). Bu boyutlar göz önüne alınarak, mevcut çalışmada turist rehberliği hizmetlerinin bir unsuru olarak mesleki yeterliliğin turist destinasyon algısı ve genel memnuniyeti üzerinde anlamlı bir etkiye sahip olduğu öngörülmüştür. Bu bağlamda bir araştırma modeli önerilerek, değişkenler arasındaki ilişki ampirik bir çalışma ile incelenmiştir.

Çalışmanın başlıca amacı: turist rehberlerinin mesleki yeterliliklerinin, turistlerin destinasyon imaj algıları ve genel memnuniyetleri üzerindeki etkisini belirlemektir. Alt araştırma amaçları ise destinasyon imaj boyutlarının tespit edilmesi ve bu boyutların genel turist memnuniyetine etkisini ortaya koymaktır. Bu çalışmadan elde edilecek sonuçların teoriye ve uygulamaya yönelik çeşitli katkıları söz konusu olacaktır. Örneğin, mevcut alınyazında destinasyon imajı ve turist memnuniyeti arasındaki ilişkinin birçok araştırmada ele alınmış olduğu görülmesine karşın (Molina vd. 2013; Veasna vd. 2013; Vong 2013), turist rehberlerinin turist destinasyon imaj algisı ve genel memnuniyeti üzerindeki etkisi az sayıda çalışmaya konu olmuştur (Güzel 2007). Elde edilecek bulgular, turist destinasyon imaj algisı ve genel memnuniyeti açısından turist rehberliği hizmetlerinin önemini ve bu bağlamda mesleki yeterliliğin oynadığı rolü teorik açıdan ortaya koyacaktır. Ayrıca, elde edilecek sonuçlar ışığında destinasyon pazarlamasına ve seyahat işletmeciliğine yönelik çeşitli stratejik uygulamaların geliştirilmesi mümkün olacaktır. Nitekim turistlerin bir destinasyonu tercih etme nedenlerini belirleyebilmek ve etkili bir destinasyon konumlandırması yapabilmek için imajı etkileyen (turist rehberi gibi) çeşitli faktörlerin incelenmesi gerekmektedir (Pike ve Ryan 2004).

Çalışmanın izleyen bölümünde bir alanyazın özeti sunulmuştur. Ardından araştırma yöntemi açıklanarak, elde edilen bulgular tartışılmıştır. Son olarak çalışmanın başlıca kısıtları ve ileride yapılabilecek araştırmalara dair bazı öneriler sunulmuştur.

\section{ALANYAZIN TARAMASI}

\section{Turist Rehberliği Mesleği ve Mesleki Yeterliliğinin Önemi}

Turistlere seyahatleri sırasında "karar anı" yaşa$\tan$ (Zhang ve Chow 2004), ulaşımı düzenleyen, bilgilerini yorumlarıyla süsleyen, problemler karşısında çözüm üreten, bilmedikleri çevrede seyahat eden ziyaretçilerin yaşadıkları zorlukları çözümleyerek, güvende olmalarını sağlayan rehberler, turistler ile bilinmeyen çevre arasında "arabulucu" görevi üstlenmektedir (Ap ve Wong 2001; Zhang ve Chow 2004). Turist deneyimi kalitesini etkileyen, onların destinasyonlarda kimi zaman daha uzun süre kalmalarını sağlayarak, ekonomik getiriye katkı sağlayan da rehberlerdir (Salazar 2012). Bazı araştırmacılara göre rehber, "gelecek turu satan kişilerdir" (Gronroos 1978; Geva ve Goldman 1991; Zhang ve Chow 2004). Ziyaretçileri sürdürülebilir turizme teşvik eden, doğal güzellikleri ve kültürel miras unsurlarını tanitan turist rehberleri, çevrenin ve milli değerlerin korunmasında rol oynayarak, çevreye duyarlı turist davranışının gelişmesine de katkıda bulunurlar (Weiler ve Kim 2011).

Ap ve Wong'a göre (2001) turist rehberinin gerek bilgi birikimi ile bir destinasyonun çekiciliklerini ve kültürünü yorumlama gücü, gerekse iletişim ve hizmet sunma becerisi aracılığıyla turistlerin bir turdan edindikleri deneyimi zenginleştirmesi, turistlerin gözünde seyahat işletmelerinin olduğu kadar destinasyonun da bir başarısı olarak algılanacaktır. Turist rehberlerinin profesyonellik anlayışları, işlerine yönelik yansıttıkları davranışlardır ve bu anlayışın gelişmesi için birtakım yeterliliklere sahip olunması gerekmektedir. Bu yeterlilikler; iyi ürün bilgisi, dil yeterliliğini de içeren iyi iletişim becerileri, hizmet 
bakımından doğru davranış (yardım sunmaya ve sayg duymaya isteklilik, empati vb.) olarak siralanabilir (Kozak ve Yetgin 2013). Turist rehberlerinin mesleki yeterlilikleri ile ilgili önemli bir çalışma Huang, Hsu ve Chan'a (2010) aittir. Huang, Hsu ve Chan'a (2010) göre turist rehberlerinin mesleki yeterlilikleri şu kriterlere dayanmaktadır: Destinasyon kültürü, turistik çekicilikler ve yerel halkın yaşam şekli ile ilgili bilgi ve doğru yorumlama gücü, mizah anlayışı, müşterilerin gereksinimlerine yönelik bilinç ve iletişim becerisidir.

\section{Algılanan Destinasyon İmajı}

Destinasyon imajı "bir destinasyona ilişkin bireyin sahip olduğu bilgileri (inançları), duyguları ve genel izlenimleri" ifade eden algılar bütünüdür. Turistik destinasyon imajı, bir destinasyonun sahip olduğu kaynaklar ve çekiciliklerle örtüşen birtakım niteliklerle ("doğal kaynaklar", "genel altyapı", "turistik altyapı", "boş zaman ve rekreasyon", "kültür, tarih ve sanat", "politik ve ekonomik faktörler", "doğal çevre", "sosyal çevre" ve "bölgenin atmosferi") değerlendirilirken (Beerli ve Martín 2004), seyahat öncesinde, esnasında ve sonrasında olmak üzere üç aşamada turist davranışını etkilemektedir (Agapito vd. 2013). Turist karar alma sürecinde objektif bilgilenme düzeyi kadar, sahip olunan izlenimler, ön yargilar, hayaller, beklentiler, duygu ve düşüncelerden oluşan imaj olgusunun belirleyiciliği söz konusudur. Bu nedenle destinasyon imaj1, hem turistlerin satın alma davranışlarını hem de satın alma sonrası davranışsal niyetlerini belirlemek açısından önemli bir araştırma konusudur (Baloglu ve McCleary 1999).

Günümüzde birçok araştırmacı destinasyon imajı kavramının bilişsel/algısal ve duygusal boyutlardan oluştuğunda görüş birliğine sahiptir (Hosany vd. 2006). Bununla birlikte bilişsel ve duygusal boyutların yanı sıra davranışsal boyutu da çalışmalarında inceleyen araştırmacılar bulunmaktadır (Pike ve Ryan 2004). Bilişsel değerlendirme, bireyin destinasyon hakkında kendi bilgi ve inançları doğrultusunda ve destinasyon niteliklerini göz önünde bulundurarak yaptığ1 değerlendirmeleri içermekte; duygusal değer- lendirme ise bireyin destinasyona karşı hissettiği duyguları ya da destinasyona karşı duyduğu bağlılı̆̆ ifade etmektedir. Destinasyon ile ilgili bilişsel ve duygusal değerlendirmeler sonucunda destinasyon genel imajı şekillenmektedir (Baloglu ve McCleary 1999).

Bilişsel ve duygusal bileşenler, imajın bir bütün olarak pozitif ya da negatif yönde algılanmasını sağlamaktadır. Bu iki bileşenin birbiriyle olan yakın ilişkisi, araştırmacıları (Moutinho 1987; Baloglu ve Brinberg 1997; Walmsley ve Young 1998; Baloglu ve McCleary 1999) imaj kavramını incelemeye yöneltmiştir (Beerli ve Martín 2004). Destinasyona karşı duyulan hisleri ifade edebilecek yüzlerce sözcük bulunabileceğini belirten Russel vd. (1981), yaygin olarak kullanilan 105 sıfatı analiz ederek, sekiz başlık altında toplamıştır. Destinasyon duygusal imaj boyutunun tespitinde keyifli/keyifsiz, canlandırıcı/miskin, dinlendirici/bunaltıcı ve heyecan verici/kasvetli zıt sıfatlarını kullanan araştırmacılar arasında Walmsley ve Jenkins (1993), Baloglu ve Brinberg (1997), Baloglu ve McCleary (1999), Beerli ve Martín (2004), Lin vd. (2007) ile Qu, Kim ve Im (2011) bulunmaktadir.

Fakeye ve Crompton (1991) bir destinasyonu hiç ziyaret etmeyen turistler ile destinasyonu daha önce ziyaret etmiş olan turistler arasındaki imaj farklılıklarını, Baloglu ve Brinberg (1997) 11 Akdeniz ülkesinin imajını, Walmsley ve Young (1998) Avustralyalı turistlerin ulusal ve uluslararası destinasyonlar için sahip oldukları imajı, Baloglu ve Mangaloglu (2001) Amerikan seyahat acentaları ve tur operatörlerinin dört farklı destinasyona (Türkiye, Mısır, Yunanistan ve İtalya) yönelik imaj algılarını ve algı farklılıklarını, Beerli ve Martín (2004) Lanzorette/Kanarya Adaları'nın turist özelliklerini ve algılanan destinasyon imajı arasında ilişkiyi, Öter ve Özdogan (2005) kültür amaçlı seyahat eden turistlerin Efes (Selçuk) yöresine yönelik algıladıkları imajı, Chen ve Tsai (2007) Tayvan'ın algılanan destinasyon imajı, seyahat kalitesi, değer, seyahat eğilimi, memnuniyet arasındaki ilişkiyi belirlemek amacıyla bilimsel çalışmalar gerçekleştirmişlerdir. Echtner ve Ritchie'nin (2003) 1975-1990 yılları arasında destinasyon imajı ile ilgili yapılmış olan 
15 araştırmayı incelediği çalışma sonucunda ise manzara, doğal çekicilikler, konukseverlik, maliyet/fiyat düzeyi araştırmacıların en fazla yararlandığı destinasyon imaj özellikleri olarak sıralanmaktadir.

\section{Turist Memnuniyeti}

Turist memnuniyeti, bir destinasyonun performansını gösteren temel etken olarak kabul edilmektedir (Korzay ve Alvarez 2005). Dwyer ve Kim'e (2003) göre, bir destinasyonun rekabet gücü, diğer destinasyonlara kıyasla sunulan mal ve hizmetlerin turistlere daha başarılı bir biçimde sunulabilme becerisinde yatmaktadır. Çeşitli araştırma sonuçları hizmet kalitesi ve değer algısının, turist memnuniyetini etkilediğini; turist memnuniyeti ile davranıssal niyet arasında bir ilişki olduğunu göstermiştir. Buna göre, tatmin olmuş turistlerin aynı destinasyona tekrar gelme ve çevresindekilere destinasyon hakkında olumlu tavsiyede bulunma ihtimalleri yüksektir (Albayrak ve Caber 2013; Vong 2013).

Pazarlama faaliyetleri ile bağlantılı olarak destinasyon özelliklerinin önem ve etkisi, genel turist memnuniyetini büyük ölçüde farklılaştırabilir (Albayrak ve Caber 2013). Bir takım destinasyon özellikleri, turistlerin destinasyona yönelik algilarında tatmin eden veya tatmin etmeyen unsurlar olarak yer alabilir (Özdemir, Çizel ve Çizel 2012). Destinasyon imaj1 ve turist memnuniyeti ile ilgili çalışmaların ortaya koyduğu üzere, olumlu bir imaja sahip olan destinasyonların turist memnuniyeti sağlama yeterlilikleri, gelen turist sayıları ve turizm gelirleri diğer destinasyonlara göre daha yüksektir (Ana vd. 2010). Turist rehberleri, destinasyonlarda sağlanan hizmetler vasitasıyla genel turist memnuniyetinden de sorumludurlar. Turist rehberlerinin performansları, tur şirketlerinin imajını etkileyerek onlara yeni iş olanakları yaratabileceği gibi, destinasyonların imajını da etkileyebilir (Geva ve Goldman 1991; Zhang ve Chow 2004). Ayrica destinasyon imajı, turist memnuniyeti, sadakati ve davranışsal niyet arasında güçlü bir ilişki bulunmaktadır (Beerli ve Martín 2004; Veasna vd. 2013). Nitekim destinasyonu tekrar ziyaret eden turistlerin genel memnuniyet algılarının, imaj üzerindeki etkisi de ilk kez gelen turistlere kıyasla daha yüksektir (Molina vd. 2013).

Destinasyon imajı ile ilgili mevcut alanyazında genellikle bilişsel imajın ele alındığı, buna karşılık bilişsel ve duygusal imaj boyutlarını bir arada ele alan araştırmaların az sayıda olduğu görülmektedir (Baloglu ve McCleary 1999; Qu, Kim ve Im 2011). Yoğun rekabet ortamında, destinasyonların imajı üzerinde hem bilişsel hem de duygusal unsurların belirleyiciliği söz konusudur. Bu sebeple hem turizm sektörü temsilcileri hem de turistler açısından destinasyon imajının oluşumunda ve yönetiminde bilişsel ve duygusal imaj unsurlarının göz önüne alınması gerekmektedir (Qu, Kim ve Im 2011). Destinasyon imajını oluşturan bu boyutlar ile ilgili turist rehberlerinin yapmış olduğu bilgilendirmeler, yönlendirmeler, sunmuş oldukları destek ve benzeri hizmetler de turistlerin destinasyona yönelik genel memnuniyetlerini etkileyebilmektedir.

\section{ARAŞTIRMA YÖNTEMI}

Araştırma modelinde (Şekil 1), turist rehberlerinin mesleki yeterliliklerinin turistlerin algıladıkları destinasyon imajı ve genel memnuniyetleri üzerinde istatistiki açıdan anlamlı bir etkiye sahip olduğu önerilmiştir.

Öne sürülen bu kavramsal ilişkilerin test edilebilmesi amacıyla bir alan araştırması yapılmıştır. Alan araştırması nicel araştırma yöntemlerinden olan anket uygulamasina dayanmaktadir. Soru formunda turist rehberlerinin mesleki yeterlilikleri Huang vd. (2010) tarafından geliştirilen yedi önerme ile genel turist memnuniyeti Veasna vd.'nden (2013) elde edilen beş önerme

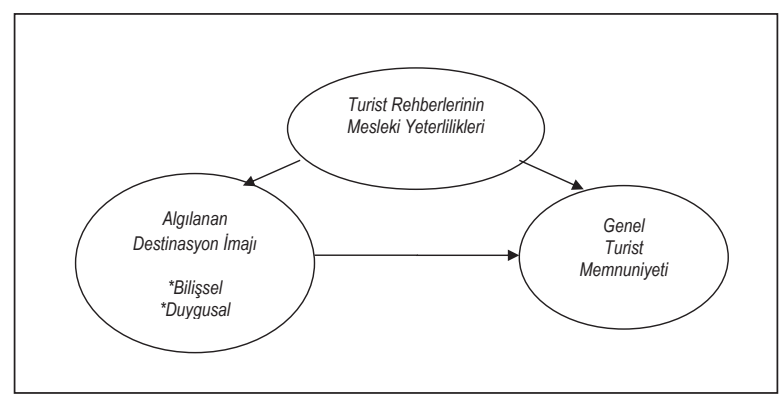

Şekil 1. Araştırma Modeli 
ile ölçülmüştür. Bilişsel destinasyon imajı Gallarza vd.'nin (2002) ile Echtner ve Ritchie (2003) yapmış olduğu araştırmalar ile Beerli ve Martín (2004) tarafından önerilen destinasyon imaj modeli esas alınarak 28 önerme ile ölçülmüştür. Destinasyona yönelik duygusal imajın belirlenmesinde Lin vd.'nin (2007) önermeleri kullanılmış olup, mevcut ölçeğin her iki tarafında, zıt sıfatların yer aldığ 1 dört soru bulunmaktadır. Bunlar: $1=$ Keyifsiz $/ 7=$ Keyifli; $1=$ Miskin $/ 7=$ Canlandırıc1; $1=$ Bunaltıc1 $/ 7=$ Dinlendirici; $1=$ Kasvetli $/ 7=$ Heyecan verici şeklindedir. Genel imaj tek önerme ile tespit edilmiştir. Önermeler yedili Likert tipi ölçek ile derecelendirilmiştir.

Anket önermelerinin anlaşılırlığının bir pilot çalışma ile ortaya konulması amaçlanmıştır. Anketin ilk bölümünde katılımcıların demografik özelliklerine ve Antalya'ya yönelik seyahatlerine ait sorular yer almıştır. İkinci ve üçüncü bölümlerde ise diğer değişkenlere ait önermeler yer almıştır. Orijinali İngilizce olan ölçek ifadeleri önce Türkçeye, daha sonra Türkçeden Almancaya çevrilmiştir. Çeviriler profesyonel turist rehberleri tarafından kontrol edilmiştir. 100 adet Alman turistin katılımı ile gerçekleştirilen pilot anket çalışması sonucunda, bütün soruların kolaylıkla anlaşıldığ 1 ve cevaplandığı görülmüştür. Verinin normal dağılıma sahip olduğu ve uç değerlerin bulunmadığı yapılan analizlerle ortaya konmuştur. Bu nedenlerle mevcut soru formunun daha sonraki aşamada yapılacak olan anket çalışmasında aynen kullanılabileceği anlaşılmıştır.

Nihai anket çalışmasında Antalya'ya gelen Alman turistlerin hedef alınması kararlaştırılmıştır. 2014 yılı verilerine göre Antalya'ya gelen Alman turist sayısı 2.987.577 olup (T.C. Kültür ve Turizm Bakanlığı 2011), bütün kitleye ulaşmanın bütçe ve zaman kısıtları açısından mümkün olmadığı göz önüne alındığında yüzde 95 güven aralığı ile 384 örnekleme ulaşmanın, yapılacak ampirik analizler için yeterli olduğu kabul edilmiştir. Bu amaçla 10 Mayıs-10 Eylül 2014 tarihleri arasında gerçekleştirilen anket çalışmasında kolayda örnekleme metodu kullanılmıştır. Bu bağlamda günübirlik olarak düzenlenen Antalya şehir turuna katılan ve tur bitiminde dönüş transferleri için şehir meydanında bulunan ve toplanma noktası olarak belirlenen iki kafeteryada oturan Alman turistler hedef alınmıştır. Kafeterya sahiplerinin izni ile her hafta tur operasyonlarının yoğun olduğu günler esas alınarak bir alan araştırması gerçekleştirilmiş̧ir. Çoğunluğunu Antalya'ya paket turlar vasıtasıyla gelmiş turistlerin oluşturduğu tur katılımcılarına çalışmanın amacı ve önemi bizzat araştırmacılar tarafından anlatılarak, yapılan anket çalışmasına gönüllü olarak katılmaları rica edilmiştir. Eksik ve hatalı doldurulan anketler elendikten sonra 307 adet kullanılabilir form kalmıştır. Hedeflenen anket geri dönüş sayısına ulaşılamamış olmasına karşın, 1.000 .000 ve üzeri evren hacmi söz konusu olduğunda yüzde 95'lik güven seviyesinde ve \pm yüzde 10 hata pay1 ile 96'nın üzerinde verinin yeterli olduğu (Yazıc1oğlu ve Erdoğan 2004: 50) göz önüne alınmış ve elde edilen verinin yapılacak analizler için yeterli görülmüştür.

\section{BULGULAR VE TARTIŞMA}

\section{Katılımcı Profili}

Anket uygulamasina katılan Alman turistlerin yüzde 52,1'ini kadın, yüzde 47,9'unu erkek katılımcılar oluşturmaktadır. Turistlerin büyük bir bölümü (yüzde 62,2) 35 yaşın altındadır. Bağlı oldukları meslek grupları incelendiğinde, çoğunluğunun (yüzde 67,1) ücretli çalışanlardan oluştuğu görülmektedir. Katılımcıların büyük bölümü (yüzde 66,1) orta gelir grubunda yer almaktadır.

Ankete katılan Alman turistlerin yüzde 42'sinin Türkiye'ye ve yüzde 70,7'sinin Antalya'ya ilk kez gelmiş oldukları tespit edilmiştir. Katılımc1ların yüzde 50,5'inin sekiz-on gün arası konaklama yapmayı tercih ettikleri, yüzde 40,39'unun ailelerden oluştuğu belirlenmiştir. Seyahat amaçlarına yönelik çoklu seçim yapılabilmesine olanak sağlanmıştır. Dinlenmek ve stresten uzaklaşmak, destinasyon tercihinde en fazla (yüzde 46,6) rol oynayan unsurlar olarak tespit edilmiştir. Seyahat planlama aşamasında seyahat acentelerinin bilgi elde etmede en fazla (yüzde 31,3) etkiye sahip unsur olduğu tespit edilmiştir. Sayfiye turizmine yönelik olanakların destinasyonun tercih edilmesinde en önemli (yüzde 31,9) paya sahip olduğu tespit edilmiştir. 


\section{Geçerlik ve Güvenilirlik Analizleri}

Ölçeklerin iç tutarlılıklarının belirlenmesinde sıklıkla kullanılmakta olan Cronbach alfa değeri, 0,70 veya üstü ise ilgili ölçeğin güvenilir olduğu kabul edilmektedir (Durmuş vd. 2011). Bilişsel destinasyon imaj1 $(0,913)$, duygusal destinasyon imajı $(0,778)$, turist rehberi mesleki yeterliliği $(0,953)$ ve genel memnuniyet $(0,897)$ ölçeklerine ait alfa katsayıları kullanılan ölçeklerin yeterli güvenirliliğe sahip olduğunu göstermiş̧ir.

\section{Destinasyon İmajının Faktör Yapısına Yönelik Analiz Sonuçları}

Alman turistlerin destinasyon bilişsel imaj boyutlarını tespit etmek maksadıyla ölçekte bulunan 28 ifade Varimax döndürme yöntemiyle açıklayıcı faktör analizine tabi tutulmuş, ardından güvenilirlik analizleri yapılmıştır. İlk olarak örneklem sayısının yeterli olup olmadığını test etmek için Kaiser-Meyer-Olkin (KMO) analizinden faydalanılmış ve oran 0,844 bulunmuştur. $\mathrm{Bu}$ değer örneklem sayısının faktör analizi için yeterli olduğunu göstermektedir (Büyüköztürk 2012). Faktör analizinin ön şartlarından olan değişkenler arasındaki ilişkinin varlığ 1 Bartlett Küresellik Testi ile gösterilmiştir $(p=0,000)$. Özdeğeri birin üstünde olan beş faktörün varyans açıklama oranı yüzde 65,23 olup, kabul edilebilir eşik değerinin üzerindedir. Önermeler arasında eş kökenliliği 0,464 olan tek ifade ("Kent mimarisi güzel bir destinasyondur"), faktörlerin içsel tutarlılıkları için yapılan Pearson korelasyon analizi değerlerinin 0,01 düzeyinde anlamlı olması ve Cronbach alfa katsayılarının $(0,732-0,887)$ ölçeğin güvenilir olduğunu göstermesi nedeniyle (Hair vd. 1998) analizden çıkarılmamıştır. Güvenilirlik analizi sonucunda ("Temiz plajlara sahiptir", "Uygun iklim koşullarına sahiptir", "Fiyatlar uygundur") önermelerinin analize dahil edilmemesi halinde, güvenilirlik değerinin artacağ 1 ve korunmaları halinde faktör yapısının bozulacağı görüldügünden, bu önermeler analizden çıkarılmiştır (Durmuş vd. 2011). Elde edilmiş olan faktörlerin içsel tutarlılığını yansıtan Cronbach alfa değerleri 0,732 ile 0,887 arasında değişmiştir. Faktör analizine tabi tutulan 25 önerme beş faktör altında toplanmıştır (Tablo 1).
Elde edilen beş faktör, sahip oldukları önermeler göz önüne alınarak "Yerel Yaşam ve Alt Yapıl Üst Yapı Hizmetleri", "Sosyal Çevre ve Olanaklar", "Doğal ve Kültürel Kaynaklar", "Turizm Hizmetleri" ve "Turist Deneyimi Kalitesi" olarak adlandırılmıştır. Elde edilen faktörlerin ortalamaları incelendiğinde, en düşük ortalamaya sahip faktörün "Yerel Yaşam ve Alt Yapul Üst Yapı Hizmetleri" (Ort. $4,38)$, en yüksek ortalamaya sahip olan faktörün ise "Turist Deneyimi Kalitesi" (Ort. 5,18) olduğu tespit edilmiştir.

\section{Değişkenler Arası Ilişkilere Yönelik Analiz Sonuçları}

Değişkenler arasındaki ilişkileri tespit etmek maksadıyla regresyon analizinden faydalanılmış ve sonuçlar Tablo 2'de gösterilmiştir. Bu regresyon modelinde, katılımciların Antalya destinasyonunda geçirdikleri tatil deneyimine yönelik genel memnuniyetleri bağımlı değişken; beş bilişsel imaj boyutu, dört duygusal imaj boyutu ve turist rehberlerinin mesleki yeterlilikleri bağımsız değişken olarak kullanılmıştır.

Regresyon modeli anlamlı olup, Alman turistlerin genel memnuniyetlerinde oluşan değişimin yüzde 48,7'si faktör analizi sonrası elde edilen beş bilişsel imaj boyutu ile yüzde 28,9'u Antalya destinasyonuna ait hissedilen dört duygusal imaj boyutu ile yüzde 38,2'si turist rehberlerinin mesleki yeterlilikleri ile açıklanmaktadır.

Sonuçlar ışı̆̆ında katılımcıların genel memnuniyetleri ile destinasyona ait algılanan beş bilişsel imaj boyutundan üçü arasında pozitif yönlü bir ilişki olduğu görülmüştür. "Sosyal Çevre ve Olanaklar" ve "Turist Deneyimi Kalitesi" bilişsel imaj boyutları ile genel memnuniyet arasinda 0,01 seviyesinde; "Turizm Hizmetleri" bilişsel imaj boyutunun ise 0,10 seviyesinde genel memnuniyet ile anlamlı bir istatistiksel ilişkiye sahip olduğu görülmüştür. "Yerel Yaşam ve Alt Yapıl Üst Yapı Hizmetleri" ve "Doğal ve Kültürel Kaynaklar" bilişsel imaj boyutları ve genel memnuniyet arasındaki ilişki istatistiksel olarak anlamlı değildir. Buna göre, öncelikle "Sosyal Çevre ve Olanaklar" bilişsel imaj boyutunun, sonrasinda ise "Turist Deneyimi Kalitesi" ile "Turizm Hizmetleri" boyutlarını iyileştirme çabalarının, Alman turistlerin Antalya destinasyonunda geçirdikleri tatil deneyimine 
Tablo 1. Destinasyon Bilişsel İmajının Faktör Yapısı

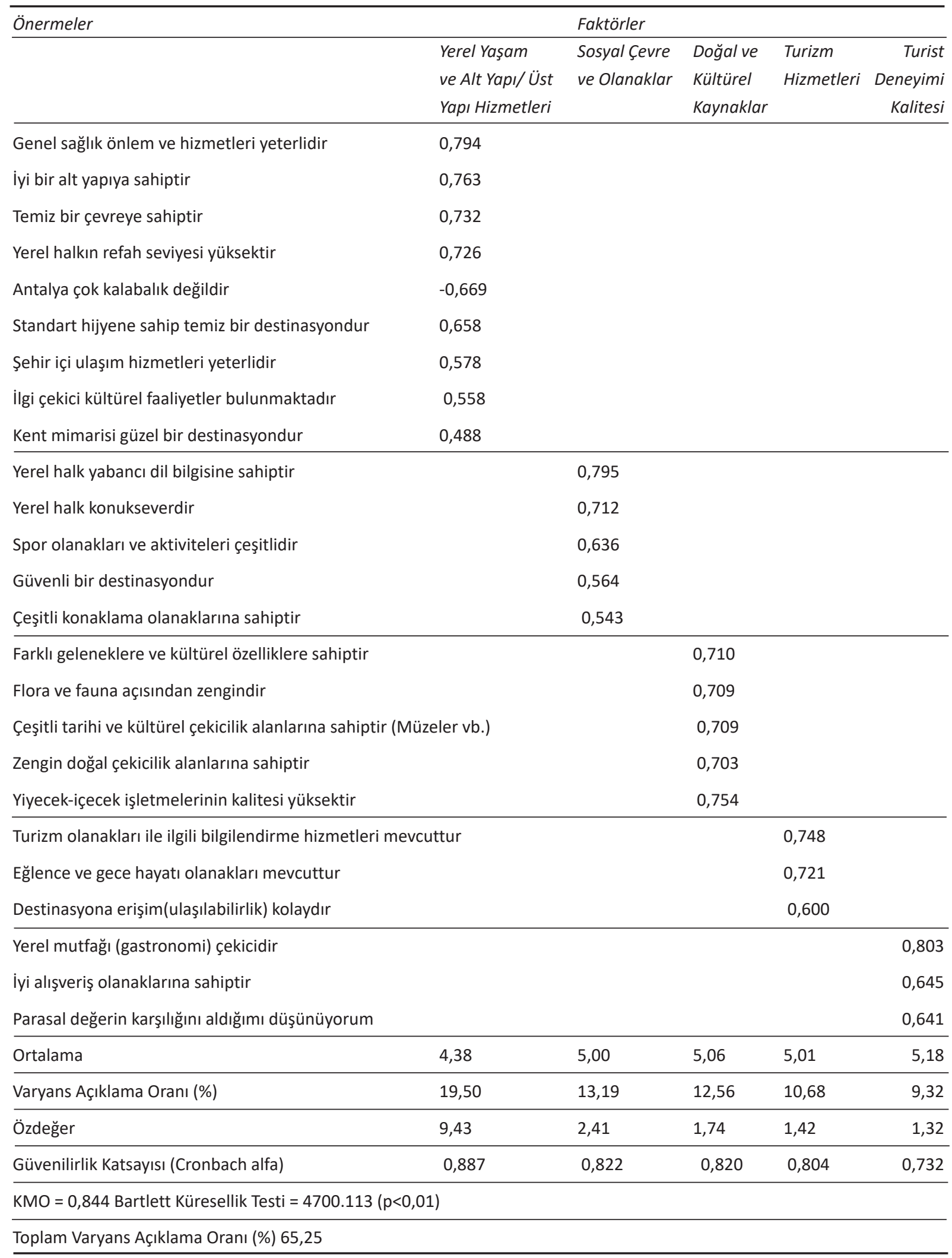


Tablo 2. Destinasyon Bilişsel ve Duygusal İmajının ve Turist Rehberlerinin Mesleki Yeterliliklerinin Genel Memnuniyete Etkisi

\begin{tabular}{|c|c|c|c|c|c|c|c|c|}
\hline \multirow[t]{2}{*}{ Bağımsız Değişkenler } & \multicolumn{2}{|c|}{ Bilişsel Imaj } & & \multicolumn{2}{|c|}{ Duygusal Imaj } & \multicolumn{3}{|c|}{$\begin{array}{l}\text { Turist Rehberlerinin } \\
\text { Mesleki Yeterlilikleri }\end{array}$} \\
\hline & b & $t$ & $p$ & B & $t$ & $p$ & b & $p$ \\
\hline Yerel Yaşam ve Alt Yapı/ Üst Yapı Hizmetleri & 0,049 & 0,939 & 0,349 & & & & & \\
\hline Sosyal Çevre ve Olanaklar & 0,353 & 5,867 & $0,000 * * *$ & & & & & \\
\hline Doğal ve Kültürel Kaynaklar & 0,053 & 0,902 & 0,368 & & & & & \\
\hline Turizm Hizmetleri & 0,105 & 1,945 & $0,053^{*}$ & & & & & \\
\hline Turist Deneyimi Kalitesi & 0,310 & 5,912 & $0,000 * * *$ & & & & & \\
\hline Keyifsiz/Keyifli & & & & 0,189 & 2,930 & $0,004 * *$ & & \\
\hline Miskin/Canlandırıcı & & & & 0,321 & 5,009 & $0,000 * *$ & & \\
\hline Bunaltıcı/Dinlendirici & & & & $-0,025$ & $-0,432$ & 0,666 & & \\
\hline Kasvetli/Heyecan verici & & & & 0,154 & 2,573 & $0,011^{* *}$ & & \\
\hline Turist Rehberlerinin Mesleki Yeterlilikleri & & & & & & 0,620 & 13,749 & $0,000 * * *$ \\
\hline $\mathrm{R} 2$ & 0,487 & 0,289 & 0,382 & & & & & \\
\hline $\mathrm{F}$ & 56,120 & 31,785 & 189,039 & & & & & \\
\hline $\mathrm{p}$ & 0,000 & 0,000 & 0,000 & & & & & \\
\hline \multicolumn{9}{|l|}{ Bağımlı Değişken: Genel turist memnuniyeti } \\
\hline$* * * p<0,01 \quad * * p<0,05 * p<0,10$ & & & & & & & & \\
\hline
\end{tabular}

yönelik genel memnuniyetlerini arttıracağı söylenebilir.

Regresyon analizi sonuçlarına göre, katılımcıların genel memnuniyetleri ile üç duygusal imaj boyutu arasında pozitif yönlü bir ilişki bulunmuştur. Sadece "Bunaltıci/Dinlendirici" boyutunun memnuniyet ile negatif yönlü bir ilişkiye sahip olduğu ve istatistiksel olarak anlamlı olmadığı sonucuna ulaşılmıştır. Genel memnuniyet ile "Keyifsiz/Keyifli" ve "Miskin/Canlandırıcl" duygusal imaj boyutları arasında istatistiksel olarak anlamlı bir ilişkinin bulunduğu sonucuna ulaşılmıştır. Benzer şekilde genel memnuniyet ile "Kasvetli/Heyecan verici" duygusal imaj boyutu arasında istatistiksel olarak anlamlı bir ilişkinin bulunduğu sonucuna ulaşılmaktadır.

"Miskin/Canlandirıcı" ( $\beta=0,321)$ duygusal imaj boyutu genel memnuniyete etki eden en önemli faktör olarak ortaya çıkarken, bunu sırasıyla "Keyifsiz/Keyifli" ile "Kasvetli/ Heyecan verici" boyut- lar takip etmektedir (sırasiyla $\beta=0,189, \beta=0,154$ ). Genel memnuniyete en düşük etkiyi "Bunaltıcl/ Dinlendirici" $(\beta=-0,025)$ boyut yapmaktadır. Bu nedenle, öncelikle "Canlandırıcı" boyutun, daha sonra "Keyifli" ile "Heyecan verici" duygusal imaj boyutlarının iyileştirilmesine yönelik çabaların, Alman katılımcıların tatil deneyimine yönelik genel memnuniyetlerini arttıracağı söylenebilir.

Alman turistlerin genel memnuniyetleri ile turist rehberlerinin mesleki yeterlilikleri arasında pozitif yönlü bir ilişki bulunurken $(\beta=0,620)$, bu ilişkinin istatistiksel olarak da anlamlı olduğu görülmektedir. Buna göre, turist rehberlerinin mesleki yeterlilikleri arttıkça Alman turistlerin Antalya destinasyonundan genel memnuniyetlerinin doğrusal olarak artacağı söylenebilir.

\section{SONUÇ VE ÖNERILER}

Bu çalışmada, turist rehberlerinin mesleki yeterliliklerinin, Antalya şehrine gelen Alman turistle- 
rin destinasyon imaj algisına ve genel memnuniyetine etkisi ortaya konmuştur. Turizm pazarlaması kapsamında ilk kez rehber yeterliliği-imajmemnuniyet ilişkilerini ele alan bir araştırmanın gerçekleştirilmiş olması, ilgili alanyazına katkı sağlamıştır. Gerçekleştirilen alan araştırması sonucunda, genel turist memnuniyeti üzerinde hem destinasyonda edinilen imaj algisının hem de turist rehberinin gösterdiği mesleki yeterlilik algısının rol oynadığı; bunun yanı sıra destinasyon imaj algısını oluşturan bilişsel ve duygusal boyutların memnuniyet üzerine farklı düzeylerde etki yaptığı gösterilmiştir.

Alman turistlerin Antalya destinasyonuna yönelik duygusal imaj boyutlarına ilişkin en yüksek ortalamaya "Keyifli" (Ort. 5,18) boyutunun sahip olduğu belirlenmiştir. Destinasyon pazarlaması çalışmalarında destinasyonun bu özelliğine dikkat çekilmesi uygun olacaktır. "Sosyal Çevre ve Olanaklar", "Turist Deneyimi Kalitesi" ile "Turizm Hizmetleri" bilişsel imaj boyutlarını iyileştirme çabalarının, turistlerin tatil deneyimlerine yönelik genel memnuniyetlerini arttıracağı görülmüştür. "Canlandırıcı", "Keyifli" ve "Heyecan verici" duygusal imaj boyutlarının iyileştirilmesine yönelik çabaların da genel memnuniyeti arttıracağ 1 öngörülmüştür. Güzel'in (2007) yapmış olduğu bir çalışmada Türkiye'yi ilk kez ziyaret eden turistler üzerinde rehberlerin daha fazla etkiye sahip olabilecekleri sonucuna varılmıştır. Bu sebeple rehberler, turist ve ülke arasında bağ kurabilecek ve onları etkileyebilecek kilit isimler olarak ortaya çıkmakta; rehberli turların ardından turistlerin Türkiye'yi ve Türk halkını daha çok sevdikleri; Türkiye ve Türk halkı hakkındaki olumsuz imajin rehberler sayesinde ortadan kalktığı saptanmıştır. Bu çalışmaya ait bulgular da turist rehberlerinin rolünü ve turist algisı üzerindeki etkisini ortaya koyma açısından Güzel' in (2007) sonuçlarını desteklemektedir.

Elde edilen sonuçlara göre, algılanan bilişsel imaj ve rehberlerin mesleki yeterlilikleri ile ilgili en düşük ortalamaya sahip önermeler: "Antalya çok kalabalık değildir" (Ort. 3,89), "Yerel halkın refah seviyesi yüksektir" (Ort. 4,03), "Temiz bir çevreye sahiptir" (Ort. 4,17) ve "İyi bir altyapıya sahiptir" (Ort. 4,37), "Tur rehberi turistik cazibe- ler hakkında bilgi sahibiydi" önermesi (Ort. 5,78) “Tur rehberi Antalya'nın kültürü hakkında bilgi sahibiydi" (Ort. 5,60) olarak sıralanmaktadır. Bu özellikler, destinasyon açısından geliştirilmesi gereken hususları oluşturmaktadır. Özellikle turist rehberlerinin Antalya'nın kültürel yapısı ve mevcut turistik çekiciliklerle ilgili beklenen performansı gösterememiş olması, önemli bir bulgudur. Turist beklentilerini karşılayamayan turist rehberi performansının altında yatan nedenlerin ileride yapılacak olan başka çalışmalarla ortaya konulması tavsiye edilebilir. Nitekim, turistlerin Antalya şehir merkezini turist rehberleri eşliğinde gezmeleri ve keşfetmeleri, detaylı ve doğru bilgilendirmeye olanak sağlayarak destinasyon imajını destekleyecek; rehberlerin bilgi, deneyim ve mesleki yeterliliklerinin ön plana çıkarılması turist memnuniyetini yükseltecektir.

Büyüker İşler ve Güzel'in (2014) Alman turistlerin kendi başlarına turistik ören yerlerini gezmek yerine, acentelerin rehberli turlarını tercih etmelerini sağlayan başlıca nedenleri araştırdıkları bir çalışma, başlıca etkili olan etkenlerin; "gezilen yerler ile ilgili doğru bilgi edinmek", “Türkiye' nin tarihi ve turistik değerlerini tanımak”, “Türkiye'yi ve Türk insanlarını yakından tanımak", "yalnız tura çıkmaktan tedirgin olmak" olduğunu göstermiştir. Buna göre turist rehberlerinin doğru bilgi verme ve tanıtma rolleri ön plana çıkmaktadır. Turist rehberleri bilgilendirme ve öğretme rollerini etkin bir şekilde kullanarak, turistlere zengin deneyimler sunabilir. Turistler bu deneyimlerini yakın çevreleri ile paylaşabilir, onlara tavsiyelerde bulunabilir veya ülkenin farklı destinasyonlarını da keşfetmek isteyebilirler.

\section{Çalışmanın Kısıtları ve Gelecek Çalışmalara Öneriler}

Her araştırmada olduğu gibi bu araştırmanın da bazı kısıtlarından söz etmek mümkündür. Bunlardan ilki verilerin toplandığ 1 destinasyonun Antalya ile sinırlandırılması nedeniyle elde edilen sonuçların genelleştirilememesidir. Bu nedenle farklı destinasyonlarda benzer çalışmalar yapılarak, elde edilen sonuçların karşılaştırılması düşünülebilir. Ayrıca ileride yapılacak olan çalış- 
malarda farklı milliyetlere sahip turistlerin alg1 farklılıklarının ortaya konulması tavsiye edilebilir. Bu tür kısıtlarına rağmen yapılan araştırmanın bir destinasyona yönelik imaj algısının tespit edilmesi açısından ilerideki çalışmalara referans oluşturacak nitelikte olduğu söylenebilir.

\section{KAYNAKÇA}

Agapito, D., Oom do Valle, P. ve Da Costa Mendes, J. (2013). The Cognitive-Affective-Conative Model of Destination Image: A Confirmatory Analysis, Journal of Travel and Tourism Marketing, 30 (5): 471-481.

Albayrak, T. ve Caber, M. (2013). The Symmetric and Asymmetric Influences of Destination Attributes on Overall Visitor Satisfaction, Current Issues in Tourism, 16 (2): 149-166.

Ana, I., Cristinel, C. ve Nicoleta, C.A. (2010). Identifying the Image of Tourist Destinations. The Case of Brasov and Poiana Brasov, Romania. Biennial International Congress. Tourism and Hospitality Industry: Tourism and Hospitality Management Conference Proceedings (ss. 88-100). Hirvatistan: Opatija.

Ap, J. ve Wong, K.K. (2001). Case Study on Tour Guiding: Professionalism, Issues and Problems, Tourism Management, 22 (5): 551-563.

Baloglu, S. ve Brinberg, D. (1997). Affective Images of Tourism Destinations, Journal of Travel Research, 35 (4): 11-15.

Baloglu, S. ve McCleary, K.W. (1999). A Model of Destination Image Formation, Annals of Tourism Research, 26 (4): 868-897.

Baloglu, S. ve Mangaloglu, M. (2001). Tourism Destination Images of Turkey, Egypt, Greece, and Italy as Perceived by US-Based Tour Operators and Travel Agents, Tourism Management, 22 (1): 1-9.

Beerli, A. ve Martín, J.D. (2004). Tourists' Characteristics and the Perceived Image of Tourist Destinations: A Quantitative Analysis - A Case Study of Lanzarote, Spain, Tourism Management, 25 (5): 623-636.

Büyüker İşler D. ve Güzel F.Ö. (2014). Tur Yönetiminde Profesyonel Turist Rehberlerinin Deneyimsel Rolü: Alman Turistlerin Kültür Turu Satın Alma Davranışına Yönelik Bir Değerlendirme. Süleyman Demirel Üniversitesi, İktisadi ve İdari Bilimler Fakültesi Dergisi, 19 (1): 125-138.

Büyüköztürk, Ş. (2012). Sosyal Bilimler İçin Veri Analizi El Kitabi. Ankara: Pegem Akademi.

Chen, C.F. ve Tsai, D. (2007). How Destination Image and Evaluative Factors Affect Behavioral Intentions?, Tourism Management, 28 (4): 1115-1122.

Durmuş, B., Yurtkoru, S.E. ve Çinko, M. (2011). Sosyal Bilimlerde SPSS'le Veri Analizi. İstanbul: Beta Basım Yayım Dağıtım.

Dwyer, L. ve Kim, C. (2003). Destination Competitiveness: Determinants and Indicators, Current Issues in Tourism, 6 (5): 369-414.
Echtner, C.M. ve Ritchie, J.B. (2003). The Meaning and Measurement of Destination Image, Journal of Tourism Studies, 14 (1): $37-48$

Fakeye, P.C. ve Crompton, J.L. (1991). Image Differences between Prospective, First-time, and Repeat Visitors to the Lower Rio Grande Valley, Journal of Travel Research, 30 (2):10-16.

Gallarza, M.G., Saura, I.G. ve García, H.C. (2002). Destination Image: Towards a Conceptual Framework, Annals of Tourism Research, 29 (1): 56-78.

Geva, A. ve Goldman, A. (1991). Satisfaction Measurement in Guided Tours, Annals of Tourism Research, 18 (2): 177-185.

Gronroos, C. (1978). A Service-Orientated Approach to Marketing of Services, European Journal of Marketing, 12 (8): 588-601.

Güzel, Ö.F. (2007). Türkiye İmajının Geliştirilmesinde Profesyonel Turist Rehberlerinin Rolü (Alman Turistler Üzerine Bir Araştırma) (Basılmamış Yüksek Lisans Tezi). Balıkesir: Balıkesir Üniversitesi Sosyal Bilimler Enstitüsü Turizm İşletmeciliği ve Otelcilik Ana Bilim Dalı.

Hair, J. F., Black, W.C., Babin, B.J., Anderson, R.E. ve Tatham, R.L. (1998). Multivariate Data Analysis. New Jersey, Upper Saddle River: Prentice hall.

Hosany, S., Ekinci, Y. ve Uysal, M. (2006). Destination Image and Destination Personality: An Application of Branding Theories to Tourism Places, Journal of Business Research, 59 (5): 638-642.

Huang, S. Hsu, C.H. ve Chan, A. (2010). Tour Guide Performance and Tourist Satisfaction: A Study of the Package Tours in Shanghai, Journal of Hospitality and Tourism Research, 34 (1): 3-33.

Korzay, M. ve Alvarez, M. D. (2005). Satisfaction and Dissatisfaction of Japanese Tourists in Turkey, Anatolia: An International Journal of Tourism and Hospitality Research, 16 (2): 176-193.

Kozak, M. A. ve Yetgin, D. (2013). Profesyonel Turist Rehberlerinin (PTR) Yetkinliklerinin Mesleki Yeterlilikler Çerçevesinde Değerlendirilmesi. 14. Ulusal Turizm Kongresi: Turizmde Yetkinlik Bildiri Kitabı (ss. 408-428). Türkiye: Ankara.

Lin, C. H., Morais, D. B., Kerstetter, D. L. ve Hou, J. S. (2007). Examining the Role of Cognitive and Affective Image in Predicting Choice Across Natural, Developed, and Theme-Park Destinations, Journal of Travel Research, 46 (2): 183-194.

Molina, R. M. Á., Frías-Jamilena, D. M. ve Castañeda-García, J. A. (2013). The Moderating Role of Past Experience in the Formation of a Tourist Destination's Image and in Tourists' Behavioural Intentions, Current Issues in Tourism, 16 (2): 107-127.

Moutinho, L. (1987). Consumer Behaviour in Tourism, European Journal of Marketing, 21 (10): 5-44.

Öter, Z. ve Özdoğan, O. N. (2005). Kültür Amaçlı Seyahat Eden Turistlerde Destinasyon İmajı: Selçuk-Efes Örneği, Anatolia: Turizm Araştırmaları Dergisi, 16 (2): 127-138.

Özdemir, B., Çizel, B. ve Bato Cizel, R. (2012). Satisfaction with All-Inclusive Tourism Resorts: The Effects of Satisfaction with Destination and Destination Loyalty, International Journal of Hospitality and Tourism Administration, 13 (2): 109-130. 
Pike, S. ve Ryan, C. (2004). Destination Positioning Analysis through a Comparison of Cognitive, Affective, and Conative Perceptions, Journal of Travel Research, 42 (4): 333-342.

Qu, H., Kim, L. H. ve Im, H. H. (2011). A Model of Destination Branding: Integrating the Concepts of the Branding and Destination Image, Tourism Management, 32 (3): 465-476.

Russel, J.A., Ward, L.M. ve Pratt, G. (1981). Affective Quality Attributed to Environments: A Factor Analytic Study, Environment and Behavior, 13 (3): 259-288.

Salazar, N.B. (2012). Community-based Cultural Tourism: Issues, Threats and Opportunities, Journal of Sustainable Tourism, 20 (1): 9-22.

T.C. Kültür ve Turizm Bakanlığ (2011). Alman Turist Verileri, http://www.antalyakulturturizm.gov.tr/TR,90683/yabanci-ziyaretci-sayilari-ve-milliyet-dagilimi-2011-20-.html, Erişim tarihi: 12 Şubat 2015.

Veasna, S., Wu, W.Y. ve Huang, C.H. (2013). The Impact of Destination Source Credibility on Destination Satisfaction: The Mediating Effects of Destination Attachment and Destination Image, Tourism Management, 36: 511526.
Vong, F. (2013). Relationships among Perception of Heritage Management, Satisfaction and Destination Cultural Image, Journal of Tourism and Cultural Change, 11 (4): 287-301.

Walmsley, D.J. ve Jenkins, J.M. (1993). Appraisive Images of Tourist Areas: Application of Personal Constructs, The Australian Geographer, 24 (2): 1-13.

Walmsley, D.J. ve Young, M. (1998). Evaluative Images and Tourism: The Use of Personal Constructs to Describe the Structure of Destination Images, Journal of Travel Research, 36 (3): 65-69.

Weiler, B. ve Ham, S.H. (2002). Tour Guide Training: A Model for Sustainable Capacity Building in Developing Countries, Journal of Sustainable Tourism, 10 (1): 52-69.

Weiler, B. ve Kim, A.K. (2011). Tour Guides as Agents of Sustainability: Rhetoric, Reality and Implications for Research, Tourism Recreation Research, 36 (2): 113-125.

Yazıcıoğlu, Y. ve Erdoğan, S. (2004). SPSS Uygulamalı Bilimsel Araştırma Yöntemleri. Ankara: Detay Yayıncilık.

Zhang, H.Q. ve Chow, I. (2004). Application of ImportancePerformance Model in Tour Guides' Performance: Evidence from Mainland Chinese Outbound Visitors in Hong Kong, Tourism Management, 25 (1): 81-91.

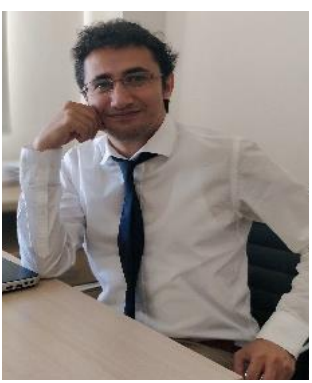

Caner ÜNAL

Anadolu Üniversitesi İşletme Fakültesi (Açıöğretim) İşletme Bölümü’nden mezun oldu (2010). Daha sonra Adnan Menderes Üniversitesi Turizm İ̧sletmeciliği ve Otelcilik Yüksekokulu Seyahat İşletmeciliği ve Turizm Rehberliği Bölümü’nden mezun oldu (2011). Yüksek lisans derecesini Akdeniz Üniversitesi'nden Turizm İşletmeciliği ve Otelcilik Ana Bilim Dalı'ndan aldı (2015). Antalya Bilim Üniversitesi'nde Araştırma Görevlisi olarak çalışmaya başladı (2017). Halen Antalya Bilim Üniversitesi'nde görev yapmaktadır. Doktora eğitimine ise Akdeniz Üniversitesi Turizm İşletmeciliği Ana Bilim Dalı'nda devam etmektedir. Temel çalışma alanları, turist rehberliği, turizm işletmeciliği, destinasyon yönetimi ve turizm pazarlamasıdır.

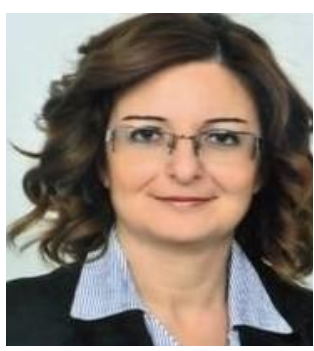

\section{Meltem CABER}

Akdeniz Üniversitesi Turizm İşletmeciliği ve Otelcilik Yüksekokulu'ndan mezun oldu (1992). Yüksek lisans derecesini Anadolu Üniversitesi Turizm ve Otel İşletmeciliği Dalı'ndan (2004), doktora derecesini Akdeniz Üniversitesi Turizm İşletmeciliği ve Otelcilik Dalı'ndan aldı (2010). Akdeniz Üniversitesi'nde çalışmaya başladı (2005). Doçentlik unvanını Turizm alanında aldı (2014). Halen Akdeniz Üniversitesi Turizm Fakültesi'nde görev yapmaktadır. Temel çalışma alanları, turizm pazarlaması, destinasyon yönetimi ve elektronik ticarettir. 